\title{
Conspecific negative density dependence in American beech
}

\author{
Benjamin S. Ramage ${ }^{*}$ and Isabel J. Mangana
}

\begin{abstract}
Background: One of the most important drivers of forest biodiversity is conspecific negative density dependence (CNDD), a reduction in performance when conspecific densities are high. While the majority of CNDD research has focused on tropical forests, evidence is mounting that CNDD may also play an important role in temperate forests. To further explore the potential reach of this phenomenon, we investigated CNDD in American beech (Fagus grandifolia) in a mature mid-Atlantic forest.

Methods: We used bivariate point pattern analyses to examine spatial relationships between large beech trees and conspecific saplings, and we also contrasted these patterns with comparable patterns for heterospecifics. In addition, to address the possibility of dispersal limitation and the associated effects on spatial patterns, we analyzed seedling density as a function of adult conspecific abundance.
\end{abstract}

Results: We found that beech saplings were more repelled from large conspecifics than large heterospecifics, despite the fact that beech seedling density was positively correlated with beech basal area. However, saplings of other canopy tree species were also repelled from adult beech trees, suggesting a general suppressive effect. Nonetheless, the discrepancy between beech seedling and sapling densities beneath adult conspecifics suggests that beech seedling survival rates were reduced in vicinity of conspecific adults.

Conclusions: Regardless of the extent to which beech inhibits heterospecific trees, a negative effect on conspecific recruits may be critical for biodiversity maintenance. Without this conspecific suppression, a dense layer of shade-tolerant beech saplings could form beneath adult beech trees. If this were to occur, beech would have a substantial head-start following canopy disturbance, and this late-successional species could potentially dominate a stand in perpetuity, through repeated disturbance cycles.

Keywords: Biodiversity, Disturbance, Dispersal limitation, Diversity, Fagus grandifolia, Janzen-Connell effects, Mid-Atlantic, Point pattern analysis, Regeneration, Temperate forest

\section{Background}

Forests are among the most diverse and complex ecosystems on Earth, and a great deal of effort has been devoted to explaining how this diversity is maintained (Hille Ris Lambers et al. 2012; Johnson et al. 2012). Most if not all forest ecosystems include at least one tree species that is highly shade-tolerant and capable of selfreplacement (i.e. "climax" species). Accordingly, monodominant stands or local clusters can form and spread (Oliver and Larson 1996; Kazmierczak et al. 2016). However, in most natural forests, mixed species stands are

* Correspondence: BenjaminRamage@rmc.edu

Biology Department, Randolph-Macon College, 204 Henry Street, Ashland, VA 23005, USA

(c) The Author(s). 2017 Open Access This article is distributed under the terms of the Creative Commons Attribution 4.0 International License (http://creativecommons.org/licenses/by/4.0/), which permits unrestricted use, distribution, and reproduction in any medium, provided you give appropriate credit to the original author(s) and the source, provide a link to the Creative Commons license, and indicate if changes were made. more common. One frequently invoked explanation for this diversity is disturbance, which removes established trees and creates habitat for early successional species (White and Jentsch 2001). While disturbance is undeniably important, other factors may also play essential roles.

One process that may be critical for the maintenance of forest biodiversity is conspecific negative density dependence (CNDD). CNDD refers to a reduction in establishment, survival, and/or growth rates when conspecific densities are high, typically owing to the local accumulation of species-specific natural enemies (e.g., pathogens, insects) and/or intraspecific competitive interactions (Terborgh 2012; Comita et al. 2014). Thus, all

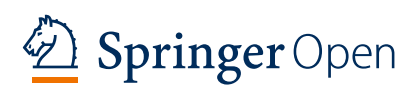


else equal, rare species should fare better than common species, and CNDD should function as a classic stabilizing mechanism (sensu Chesson 2000). CNDD is best known in the context of the Janzen-Connell Hypothesis, which asserts that tropical rainforest diversity is maintained by strong CNDD (Janzen 1970; Connell 1971). However, CNDD does not necessarily explain diversity beyond very local scales, and thus it can operate even in temperate systems with low regional species diversity (Packer and Clay 2000; Hille Ris Lambers et al. 2002). Despite decades of being largely ignored outside the tropics, several recent studies have demonstrated that CNDD is common and widespread in temperate forests (Johnson et al. 2012; Zhu et al. 2015; Bennett et al. 2017).

CNDD can be investigated in several ways including manipulative seedling survival experiments (Reinhart et al. 2012; Fricke et al. 2014), large-scale assessments of co-occurrence patterns between juveniles and adults (e.g. Johnson et al. 2012), and fine-scale spatial analyses (e.g. Johnson et al. 2014). Spatial point pattern analyses may be particularly effective at revealing subtle, highly localized effects that have occurred over years or decades. If conspecific adults reduce juvenile survival and/ or growth rates, small trees should occur less frequently near mature conspecifics (although if the species in question is dispersal-limited, the high seed input near adult conspecifics must also be considered). As an example, Johnson et al. (2014) found that many tree species in a forest in the eastern United States exhibited patterns in which small trees were over-dispersed from conspecific adults. Similarly, Wiegand et al. (2007) found that recruits of Shorea congestiflora, the most abundant species in a Sri Lankan forest dynamics plot, were overdispersed with respect to conspecific adult trees.

American beech (Fagus grandifolia) is a particularly interesting subject for temperate CNDD research given its extreme shade tolerance and highly localized seed dispersal (Tubbs and Houston 1990; Wagner et al. 2010). With these traits, American beech is a classic example of a late successional species, and one that would seem to have the potential to dominate forests in the absence of disturbance. The most compelling evidence of CNDD in temperate systems comes from black cherry (Prunus serotina; Packer and Clay 2000; Packer and Clay 2003; Reinhart et al. 2005), an early successional tree species, so little is known about the extent to which CNDD helps to maintain diversity in late successional forests. Furthermore, current research provides mixed evidence about whether American beech exhibits CNDD. On the one hand, Canham et al. (2006) found that growth rates of established American beech trees were inhibited by proximate conspecifics, and Zhu et al. (2015) inferred negative effects of American beech adults on conspecific seedling-to-sapling recruitment rates. In contrast,
Reinhart et al. (2012) found no evidence of CNDD in American beech via either a seedling planting experiment or an analysis of an existing continental-scale data set (USDA Forest Service Forestry Inventory and Analysis data). Similarly, Murphy and McCarthy (2017) found that American beech survival was unaffected by conspecific neighbors, and that growth rates were weakly positively associated with conspecific density. In addition, American beech is sometimes found in nearly monodominant stands, and patterns suggesting self-replacement have been documented (Tubbs and Houston 1990; Arii and Lechowicz 2002).

The objective of our research was to assess the evidence for CNDD in American beech in a mature midAtlantic forest. We used bivariate point pattern analyses to examine spatial relationships between large American beech trees and conspecific saplings, and we also compared these patterns to comparable patterns for heterospecifics. In addition, to address the possibility of dispersal limitation and the associated effects on spatial patterns, we analyzed seedling density as a function of adult conspecific abundance.

\section{Methods}

Study site

Field research was conducted at the Randolph-Macon College Martin Marietta Field Station in Doswell, Virginia. The site is 55 ha in size, with approximately half covered by mature, naturally regenerated, deciduous forest that originated at least 70 years prior to data collection. The canopy is dominated by American beech, yellow poplar (Liriodendron tulipifera), and several oak (Quercus) and hickory (Carya) species. The subcanopy layer is dominated by American holly (Ilex opaca) and abundant small stems of American beech, and also includes flowering dogwood (Cornus florida), eastern redbud (Cercis canadensis), and American hornbeam (Carpinus caroliniana). The terrain is gently rolling, with slopes rarely exceeding $20 \%$, and the elevation is approximately $70 \mathrm{~m}$ above sea level. The site lies near the eastern edge of the Piedmont geologic region, which is characterized by deep weathering and high geological complexity (Dietrich 1988). The local climate is humid subtropical (Köppen climate classification), with hot summers (mean July high $=31.1{ }^{\circ} \mathrm{C}$ ) and relatively mild winters (mean January low $=-2.1{ }^{\circ} \mathrm{C}$ ), and very consistent precipitation throughout the year (average annual total $=$ 1108 mm) (NOAA National Climatic Data Center).

\section{Field sampling}

Data collection occurred in eight plots randomly located in areas of upland, mature, naturally regenerated, deciduous forest that exhibited no evidence of natural or anthropogenic disturbance (Additional file 1: Figure S1). 
In the summer of 2014, we surveyed tree regeneration in 3-x-1 m subplots, with four subplots per plot (see Additional file 1: Figure S2 for detailed layout). Within each subplot, we identified all tree seedlings, which we defined as individuals that belonged to species capable of reaching at least $10 \mathrm{~m}$ in height and that were: a) woody at ground level (i.e. extremely small and delicate individuals were ignored, primarily because most of these individuals could not be identified), b) $<3 \mathrm{~cm}$ diameter at breast height $(\mathrm{DBH})$ and $\mathrm{c}$ ) not of basal or root sprout origin. All tree seedlings were tallied and inspected for evidence of browse damage (e.g. by white-tailed deer; Odocoileus virginianus). In the summer of 2015, we mapped trees $\geq 3 \mathrm{~cm} \mathrm{DBH}$ in these same plots (circular plots with a radius of $23 \mathrm{~m} ; 1 / 6$ hectare). Species not capable of reaching canopy height (e.g. flowering dogwood, eastern redbud) were omitted from our measurements. All trees were identified to species and inspected to determine seed vs. sucker origin (following the methods in Beaudet and Messier (2008)); in the latter case, clumps of vegetatively linked individuals were recorded. Across the eight plots, we measured and mapped a total of 1622 trees.

\section{Analysis}

All analyses focused on American beech, as no other species in our study area were sufficiently abundant across plots and size classes for meaningful assessment of CNDD. However, for comparative purposes, we also conducted some analyses with "all other canopy species" (pooled into a single category) and smaller size classes of American holly (individually). Small stems of American holly were examined individually because of their high densities, which enabled robust statistical analysis, and the similar shade tolerances of American holly and American beech (Stutz and Frey 1980; Grelen 1990; Tubbs and Houston 1990), which allowed for a useful comparison presented in the Discussion.

First, to assess dispersal limitation in American beech, we analyzed seedling density as a function of adult conspecific abundance. We examined these patterns at two spatial scales: a) subplot-level seedling counts as a function of conspecific basal area (BA) within $10 \mathrm{~m}$ of each subplot, and b) plot-level seedling counts (mean across all four subplots) as a function of the conspecific BA in the entire $23 \mathrm{~m}$ radius plot. For comparison, and to account for any general inhibitive effects of mature American beech on seedling establishment, we also examined relationships between American beech BA and seedling densities of both American holly and all other canopy species. In all cases, to capture early establishment only, we excluded seedlings $>30 \mathrm{~cm}$ in height (matching Johnson et al. 2014). Second, we conducted similar analyses relating plot-level densities of "saplings" (trees 3-10 cm DBH) to plot-level American beech BA. Saplings were mapped throughout the entire plot, but unlike the analyses described below, this initial assessment was non-spatial.

Third, we conducted bivariate point pattern analyses to examine fine-scale spatial relationships between different species and size classes. We individually analyzed American beech and American holly, and once again pooled all other canopy species into a single category (due to low numbers for each individually). With regard to size classes, stems were divided into saplings and "large trees" (trees $\geq 20 \mathrm{~cm}$ DBH). Trees in between these two size classes $(10-20 \mathrm{~cm}$ DBH) were excluded from our spatial analyses to ensure that large trees have the potential to disproportionately affect saplings (and not vice versa). In other words, it would make little sense to assume that a $10.1 \mathrm{~cm} \mathrm{DBH}$ tree has a qualitatively different effect on its local neighborhood than a $9.9 \mathrm{~cm}$ DBH tree. American holly was abundant only in the sapling size class, and thus our analysis of American holly saplings is done for comparison with American beech saplings, not for investigating CNDD in American holly.

We used bivariate pair correlation functions (Illian et al. 2008; Law et al. 2009), with associated confidence envelopes, to quantify the spatial positioning of sets of points (two sets at a time), relative to each other. For instance, an analysis of American beech saplings and American beech large trees reveals the extent to which saplings are clustered, randomly arranged, or overdispersed around large conspecifics. For comparative purposes, we conducted all of the following bivariate point pattern analyses: a) American beech saplings with respect to American beech large trees, b) American beech saplings with respect to large trees of all other canopy species, c) American holly saplings with respect to American beech large trees, d) American holly saplings with respect to large trees of all other canopy species, e) saplings of all other canopy species with respect to American beech large trees, and f) saplings of all other canopy species with respect to large trees of all other canopy species. All point pattern analyses were done separately within each plot.

While visually comparing the results of these bivariate pair correlation functions is illuminating, we also formally assessed the significance of the difference between the results of several different analyses. Specifically, for each sapling group (American beech, American holly, and other canopy species), we determined if the clustering around large American beech trees differed significantly from the clustering around large trees of all other canopy species. To determine the significance of the difference, we used an approach similar to Larson et al. (2015) and Janik et al. (2014), including a comparable 
null model ("random labeling"). We repeated the following steps 1000 times to generate null distributions for our bivariate pair correlation functions: 1) shuffle labels across large trees (American beech vs. all other canopy trees), 2) calculate both bivariate pair correlation functions (sapling clustering around American beech and sapling clustering around all other canopy trees), and 3) subtract one set of resulting values from the other. Next, we calculated a 95\% confidence envelope for the simulated differences between groups (2.5th through 97.5th percentile), and determined the distance bands for which the actual difference between groups departed from the confidence envelope.

Analyses were conducted with the statistical software $R$ and the supplemental package spatstat, which is specifically designed for spatial analysis. In our bivariate pair correlation functions, we analyzed successive distances from 1 to $10 \mathrm{~m}$, with the bandwidth (the width of the concentric ring analyzed) consistently set to $2 \mathrm{~m}$; for instance, at a distance of $5 \mathrm{~m}$ and a bandwidth of 2, all saplings between 4 and $6 \mathrm{~m}$ are analyzed. For all pair correlation functions, we used Ripley's isotropic edge correction. Secondary stems (all stems other than the largest within a multi-stemmed clump) were excluded from point pattern analyses because these stems are likely subsidized by larger ramets, and thereby effectively function as lower branches. As such, basal sprouts within the sapling size class were ignored and spatial patterns of saplings are specifically for seed origin saplings (although this is an inconsequential detail given that analyses with basal sprouts included yielded qualitatively identical results). While American beech sprouts are common in more northern regions, on steep slopes, in areas where roots have been disturbed, and in stands affected by beech bark disease (Held 1983; Cleavitt et al. 2008), basal and root sprouts were rare at our study site, which is beyond the current range of beech bark disease (Virginia Department of Forestry 2014).

\section{Results}

American beech seedling density was positively and significantly correlated with American beech $\mathrm{BA}$ at the subplot level (Fig. 1a; $p<0.001$ ) and plot level (Fig. 1b; $p$ $<0.001$ with outlying plot, $p=0.002$ without outlying plot). In contrast, American beech sapling density was unrelated to American beech BA, and there was actually a non-significant hint of a negative relationship (Fig. 1c; $p=0.1764$ with outlying plot, $p=0.669$ without outlying plot). American beech BA had no apparent effect on recruits of American holly (individually analyzed) or all other canopy species combined; in both cases, nonsignificant relationships were found for seedlings at the subplot level, seedlings at the plot level, and saplings $(p>0.1$ in all cases; Additional file 1: Figure S3).
Our point pattern analyses provide greater resolution to the preliminary sapling findings noted above. American beech saplings were generally less clustered around large conspecifics than they were around large trees of other canopy species (Fig. 2). This difference was significant in 2 plots (at short distances), borderline significant in 3 plots (at short or medium distances), and qualitatively similar but not significant in 2 others. Only one plot exhibited the opposite pattern, and the difference was non-significant. In contrast, the spatial patterns of American holly saplings did not differ consistently around large American beech trees as compared to large trees of all other canopy species (Additional file 1: Figure S4). Saplings of all other canopy species (combined) exhibited patterns similar to those of American beech saplings (some apparent repulsion from large American beech trees, relative to other canopy tree species), but the differences in this case were less pronounced (Additional file 1: Figure S5).

\section{Discussion}

Our results provide strong evidence of CNDD in American beech. Although our spatial analyses suggest that beech has a general inhibitory effect on tree regeneration, we have also shown that beech seedlings establish disproportionately beneath large beech trees. These findings are consistent with the pronounced dispersal limitation previously documented for American beech (Tubbs and Houston 1990; Wagner et al. 2010). If beech seedling survival rates are unaffected by proximity to mature beech trees, our plot-level sapling analyses and bivariate point pattern analyses should have revealed positive associations between beech saplings and large beech trees. Accordingly, our results demonstrate higher mortality rates for beech seedlings when in the vicinity of conspecific adults (i.e. CNDD).

It is tempting to conclude that the deep shade produced by mature American beech canopies simply inhibits all tree regeneration, both conspecific and heterospecific. After all, photosynthetically active radiation (PAR) levels beneath beech canopies, which cast especially deep shade relative to co-occurring species, have been documented at less than $1 \%$ of the PAR available above the canopy (Messier and Bellefleur 1988; Beaudet et al. 2002). However, shade-induced suppression does not seem to be the only factor. First, saplings of American holly, the only other species in our dataset with enough stems for individual analysis, were randomly distributed with respect to mature beech trees. This is not particularly surprising given the extreme shade tolerance of holly (Stutz and Frey 1980), but given that beech exhibits comparable shade tolerance (Grelen 1990; Tubbs and Houston 1990), we would expect beech regeneration to be tolerant of the same conditions (namely the shade beneath adult conspecifics). Second, saplings of all other canopy species 

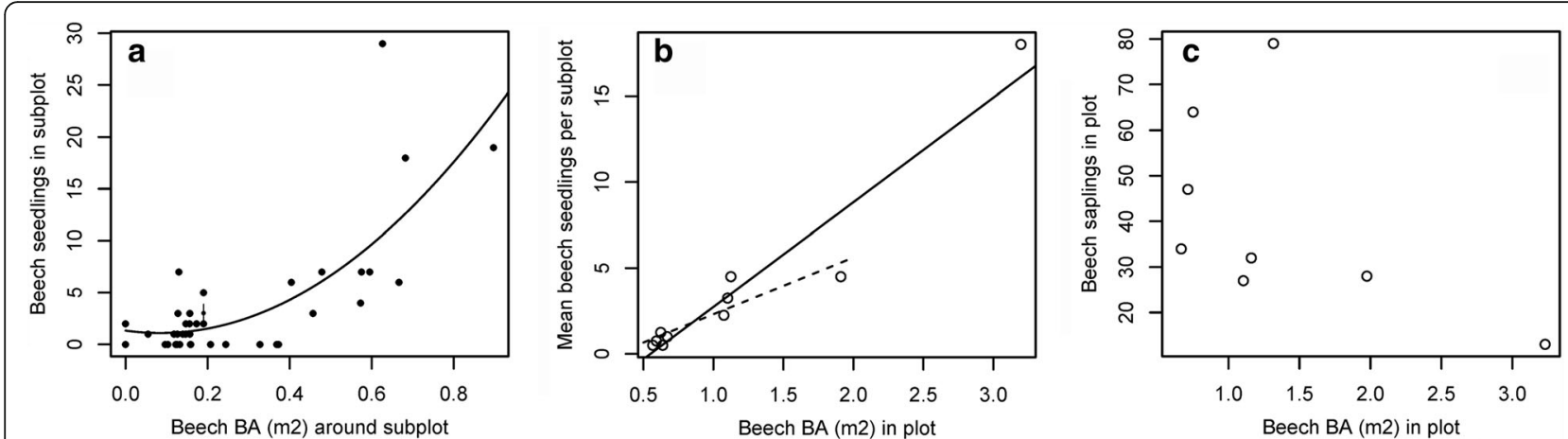

Fig. 1 American beech regeneration as a function of American beech basal area. a subplot-level seedling density, with basal area calculated within a $10 \mathrm{~m}$ radius around each seedling subplot. b plot-level seedling density, with regression lines shown for fits with and without the outlying plot. $\mathbf{c}$ plot-level sapling density

(combined), many of which are less shade-tolerant, exhibited repulsion patterns around mature beech trees that were less pronounced than those for beech saplings. As such, while the deep shade beneath American beech canopies almost certainly hinders tree regeneration (Messier and Bellefleur 1988; Poulson and Platt 1996), our results suggest that another species-specific mechanism is also at work.

Potential mechanisms of CNDD in American beech remain unknown, and many different types of damaging agents could be responsible. For instance, Fricke et al. (2014) found that insects, fungal pathogens, and rodents all contributed to CNDD in a tropical forest. One interesting possibility is Grylloprociphilus imbricator (the beech blight or "boogie woogie" aphid), an insect pest that feeds exclusively on beech (Cook-Patton et al. 2014). G. imbricator forms dense colonies on lower branches and thick fungal masses of the sooty mold Scorias spongiosa develop on the honeydew secreted by these aphids, which drips onto the ground and vegetation
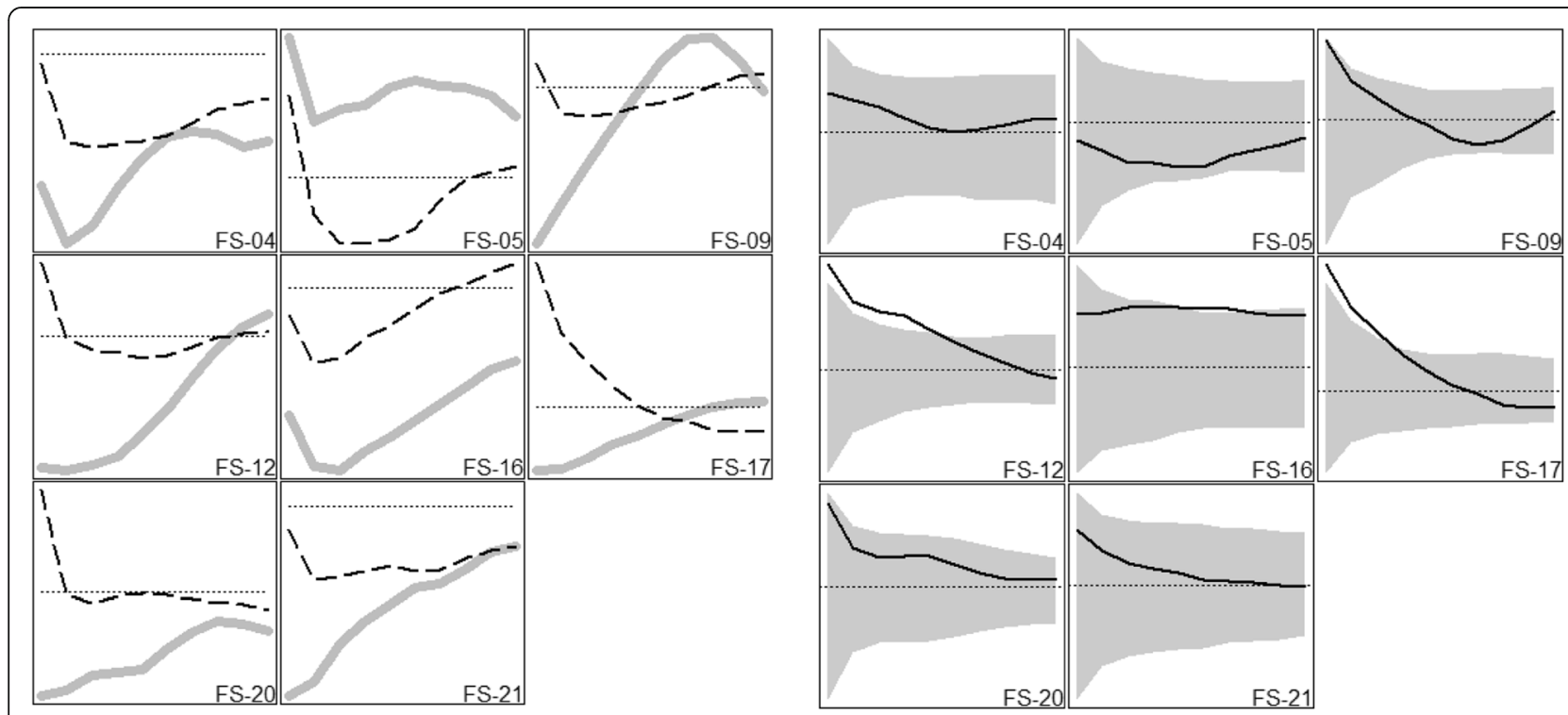

Fig. 2 Spatial patterns of American beech saplings around large American beech trees and large trees of all other species. Vertical axes indicate bivariate pair correlation function values (higher values represent increased clustering), and horizontal axes indicate distance from large trees (ranging from $1 \mathrm{~m}$ at the far left to $10 \mathrm{~m}$ at the far right of each panel). Each panel displays results for an individual plot. In the panels without confidence envelopes (left side), thick grey lines represent large American beech trees, dashed black lines represent large trees of all other species, and dotted horizontal lines indicate complete spatial randomness (clustering above, repulsion below). The panels with confidence envelopes (right side) display the difference between the two lines on the corresponding left panel (large trees of all other species minus large American beech trees). The dotted horizontal line identifies the position on the vertical axis where the difference is zero, and extensions above or below the confidence envelope indicating significant differences. As an example, in plot FS-17, American beech saplings are clustered around large trees of other species but repulsed from large American beech trees (at short distances) 
beneath. This sooty mold likely inhibits the growth of all vegetation upon which it grows, but the aphids themselves are thought to have minimal effects on mature beech trees (Cook-Patton et al. 2014). However, the direct effects of these aphids on beech seedlings are unknown, and it is possible that beech regeneration is more prone to aphid colonization when in close proximity to conspecific adults. Another possible cause of CNDD in American beech is Epifagus virginiana (beechdrops), a parasitic plant that persists exclusively on beech roots and is most common and abundant in areas of high beech density (Tsai and Manos 2010; Abbate and Campbell 2013). Like the preceding example, this parasite is not believed to cause significant damage to mature beech trees, but to the best of our knowledge no previous research has investigated its potential effects on beech regeneration. G. imbricator and E. virginiana are both common at our study site (personal observations), but a wide variety of other, less visible mechanisms (e.g. plant-soil feedbacks; Bennett et al. 2017) could be involved.

Previous investigations of CNDD in American beech have yielded mixed results. While some studies are consistent with our findings (Canham et al. 2006; Zhu et al. 2015), others have failed to detect CNDD. Murphy and McCarthy (2017) studied an Ohio forest and found that growth and survivorship of beech trees $>2.5 \mathrm{~cm}$ DBH was little affected by either conspecific or heterospecific neighbors. Similarly, spatial patterns of recruits (stems $\geq$ $1 \mathrm{~cm}$ DBH that appeared after the last census) were randomly distributed with respect to adult beech trees. However, these patterns were not compared to initial seedling establishment patterns or to the spatial patterns of beech recruits around heterospecific adults, and stems below the $1 \mathrm{~cm} \mathrm{DBH}$ threshold were not analyzed. Reinhart et al. (2012) used two very different approaches to assess CNDD, neither of which revealed any such evidence for American beech. First, they analyzed existing Forest Inventory and Analysis (FIA) data (for eastern Tennessee and western North Carolina only) and found that beech regeneration density was highly correlated with adult conspecific abundance; accordingly, they identified beech as a self-facilitating species. However, their regeneration counts included seedlings down to $30 \mathrm{~cm}$ in height, and thus their analysis does not account for mortality between the seedling and sapling stages. As such, these results are consistent with our finding that initial seedling establishment was highly correlated with adult conspecific abundance. Second, they conducted a seedling survival experiment (in the mountains of North Carolina), which also revealed no evidence of CNDD: beech seedlings had higher survival rates near conspecifics than near heterospecifics. However, their field experiment coincided with a major drought, which almost certainly affected the results (nearly $100 \%$ of beech seedlings died near heterospecifics). In these arid conditions, the deep shade beneath beech canopies may have proven beneficial and the detrimental effects of species-specific natural enemies may have been reduced. Neither of these studies examined survival rates between the seedling and sapling stages, and it is possible this is where CNDD in American beech is most pronounced. Strongly supporting this assertion are the results of Zhu et al. (2015). This paper also examined the FIA database, but focused on recruitment dynamics instead of static patterns (and spanned a much larger geographic area), and found clear evidence that beech seedling-to-sapling recruitment rates were negatively affected by adult conspecifics (with no significant effects from adult heterospecifics). In summary, to the best of our knowledge, all available data is consistent with the claim that beech is subject to CNDD between the seedling and sapling stages.

Even if CNDD at the seedling-to-sapling transition is widespread for American beech, it may not be universally meaningful since basal and root sprouting are prevalent in some stands and regions. Given that sprouts receive subsidies from larger trees (Takahashi et al. 2010), they function more like lower branches than juveniles struggling to survive. Furthermore, sprouts are necessarily located near adult conspecifics, and thus when sprouting is abundant - which may occur for a variety of reasons - spatial patterns should starkly contrast with those we have documented. Beech sprouting is common on upper slopes, possibly due to more erosion and root exposure, while seed regeneration is more common on lower slopes, and spatial patterns shift across slope positions accordingly (Takahashi et al. 2010). Sprouting is also more common on harsher sites (farther north and/ or higher elevation) and where beech roots have been injured by management operations or natural factors (Held 1983; Tubbs and Houston 1990; Cleavitt et al. 2008; Takahashi et al. 2010). In addition, many American beech stands are heavily impacted by beech bark disease, which leads to tremendous root sprouting and the formation of "beech thickets" that are clustered around dead and dying adults (Wagner et al. 2010; Giencke et al. 2014). While beech bark disease has been heavily impacting beech stands in the northern US for decades (Busby and Canham 2011; Giencke et al. 2014), it remains absent from most of the southeast, with damage in this region documented only in higher elevations in the Appalachian mountains (Virginia Department of Forestry 2014). Overall, we cannot assert that American beech exhibits consequential CNDD in all situations, but it is possible that our findings are representative of unmanaged lower elevation beech stands in the mid-Atlantic and southeastern United States. 
Given the major forest regeneration problems associated with high white-tailed deer densities in much of the eastern United States (Rooney and Waller 2003; Côté et al. 2004), it is reasonable to wonder if low rates of sapling recruitment beneath beech canopies might be driven in part by deer herbivory. However, for the reasons detailed below, this is highly unlikely. We recorded browse damage on all tallied seedlings and found that American beech had very low browse rates (only $4 \%$ of all beech seedlings). In contrast, 12 other common tree species at our study site had higher browse rates, with ten species exceeding 30\% and four species exceeding $40 \%$. These results are not surprising since several studies have found that the effects of deer browse on beech seedlings were either non-existent or trivial relative to other cooccurring tree species (Liang and Seagle 2002; Krueger et al. 2009; Long et al. 2007). Furthermore, for our results to be confounded by deer browse, it would not be enough for deer to consume a high proportion of beech seedlings: the effects of deer on beech seedling survival would also have to be more severe in the vicinity of adult beech trees. This could happen for two reasons. First, deer might preferentially browse beech seedlings in areas of high beech density; we investigated this possibility and found no relationship between browse rates and beech abundance (results not shown). Second, it is possible that deer browse beneath adult conspecifics could be more likely to cause seedling death or stunting (e.g. perhaps due to lower light levels and reduced photosynthetic reserves). We cannot definitively reject this second possibility, but given the very low rates of deer browse on beech seedlings, major confounding effects seem highly unlikely. Overall, there is no reason to suspect that our findings are influenced by high deer densities.

\section{Conclusions}

While we have provided evidence of reduced American beech seedling survival beneath adult conspecifics, our results do not directly address diversity maintenance. Does CNDD in beech help to limit the formation of mono-specific beech clusters? And is self-inhibition relevant to diversity maintenance if most other tree species are also inhibited? We assert that the answer to both questions is "yes", and our rationale rests on the inevitably of disturbance. If a dense understory layer of small beeches formed beneath large beech trees, which might be expected given beech's dispersal limitation, seedling establishment patterns, and extreme shade tolerance, these subcanopy beeches would be poised to quickly reclaim dominance after canopy disturbance. And this may be what happens in beech stands with abundant sprout regeneration, where small stems are positively correlated with adult conspecifics (Takahashi et al. 2010;
Giencke et al. 2014). As such, the CNDD that we have documented in the understory of a mature undisturbed forest may be critical for the increase in diversity that occurs post-disturbance, at least in stands where advance regeneration is primarily of seed origin. Accordingly, the interaction between CNDD and disturbance, as opposed to either acting independently, likely prevents the perpetual dominance of beech on suitable sites. We suggest that this interactive mechanism of diversity maintenance may be broadly applicable to latesuccessional temperate forests, but proper tests of our hypothesis will require research that simultaneously investigates both CNDD and disturbance.

\section{Additional files}

Additional file 1: Field sampling layout and supplemental results. (DOCX $1812 \mathrm{~kb}$ )

Additional file 2: Raw data for all analyses presented in this paper. (XLSX $103 \mathrm{~kb})$

\section{Acknowledgements}

In addition to the funders noted below, we thank Martin Marietta Materials for field site access and maintenance, and Olivia Latham and Kali Carroll for field assistance.

\section{Funding}

This project was funded by the Klein-Maloney Fellowship, the Schapiro Undergraduate Research Fellowship, and the Chenery Research Grant.

Availability of data and materials

All raw data are provided in Additional file 2.

Authors' contributions

BR designed the study and established the overall framework for the paper. BR and IM jointly collected field data, performed statistical analyses, and drafted the manuscript. Both authors approve of the final submission.

\section{Competing interests}

The authors declare that they have no competing interests.

Received: 4 March 2017 Accepted: 10 May 2017

Published online: 03 June 2017

\section{References}

Abbate AP, Campbell JW (2013) Parasitic Beechdrops (Epifagus virginiana): A possible ant-pollinated plant. Southeastern Naturalist 12:661-665. doi:10. $1656 / 058.012 .0318$

Arii K, Lechowicz MJ (2002) The influence of overstory trees and abiotic factors on the sapling community in an old-growth Fagus-Acer forest. Ecoscience 9: 386-396

Beaudet M, Messier C (2008) Beech regeneration of seed and root sucker origin: A comparison of morphology, growth, survival, and response to defoliation. Forest Ecol Manage 255:3659-3666. doi:10.1016/j.foreco.2008.03.010

Beaudet M, Messier C, Canham CD (2002) Predictions of understorey light conditions in northern hardwood forests following parameterization, sensitivity analysis, and tests of the SORTIE light model. Forest Ecol Manage 165:235-248. doi:10.1016/S0378-1127(01)00621-1

Bennett JA, Maherali H, Reinhart KO, Lekberg Y, Hart MM, John K (2017) Plant-soil feedbacks and mycorrhizal type influence temperate forest population dynamics. Science 355:181-184. doi:10.1126/science.aai8212

Busby PE, Canham CD (2011) An exotic insect and pathogen disease complex reduces aboveground tree biomass in temperate forests of eastern North America. Can J Forest Res 41:401-411. doi:10.1139/X10-213 
Canham CD, Papaik MJ, Uriarte M, McWilliams WH, Jenkins JC, Twery MJ (2006) Neighborhood analyses of canopy tree competition along environmental gradients in New England forests. Ecol Appl 16:540-554

Chesson P (2000) Mechanisms of maintenance of species diversity. Ann Rev Ecol Syst 31:343-366

Cleavitt NL, Fairbairn M, Fahey TJ (2008) Growth and survivorship of American Beech (Fagus grandifolia Ehrh.) seedlings in a Northern hardwood forest following a Mast Event. J Torrey Bot Soc 135:328-345

Comita LS, Queenborough SA, Murphy SJ, Eck J, Xu KY, Krishnadas M, Beckman N, Zhu Y, Gómez-Aparicio L (2014) Testing predictions of the Janzen-Connell hypothesis: a meta-analysis of experimental evidence for distance- and density-dependent seed and seedling survival. J Ecol 102:845-856. doi:10. $1111 / 1365-2745.12232$

Connell JH (1971) On the role of natural enemies in preventing competitive exclusion in some marine animals and in rain forest trees. In: Dynamics of populations (eds Den Boer PJ, Gradwell G.). Wageningen, The Netherlands: Centre for Agricultural Publishing and Documentation. p 298-312

Cook-Patton SC, Maynard L, Lemoine NP, Shue J, Parker JD (2014) Cascading effects of a highly specialized beech-aphid-fungus interaction on forest regeneration. PeerJ 2:e442. doi:10.7717/peerj.442

Côté SD, Rooney TP, Tremblay JP, Dussault C, Waller DM (2004) Ecological impacts of deer overabundance. Ann Rev Ecol Evol Syst 35:113-147. doi:10.1146/ annurev.ecolsys.35.021103.105725

Dietrich RV (1988) Geology and Virginia. University of Virginia Press, Charlottesville

Fricke EC, Tewksbury JJ, Rogers HS (2014) Multiple natural enemies cause distance-dependent mortality at the seed-to-seedling transition. Ecol Lett 17: 593-598. doi:10.1111/ele.12261

Giencke LM, Dovčiak M, Mountrakis G, Calejonathan A, Mitchellmyron J (2014) Beech bark disease: spatial patterns of thicket formation and disease spread in an aftermath forest in the northeastern United States. Can J Forest Res 44 : 1042-1050. doi:10.1139/cjfr-2014-0038

Grelen HE (1990) Ilex opaca Ait. American holly. In: Silvics of North America. Department of Agriculture, Forest Service, Washington, D.C, U.S

Held ME (1983) Pattern of Beech Regeneration in the East-Central United States. Bull Torrey Bot Club 110:55-62. doi:10.2307/2996517

Hille Ris Lambers J, Clark JS, Beckage B (2002) Density-dependent mortality and the latitudinal gradient in species diversity. Nature 417:732-735. doi:10.1038/ nature00809

Hille Ris Lambers J, Adler PB, Harpole WS, Levine JM, Mayfield MM (2012) Rethinking community assembly through the lens of coexistence theory. Ann Rev Ecol Evol Syst 43:120830113150004. doi:10.1146/annurev-ecolsys-110411-160411

Illian DJ, Penttinen PA, Stoyan DH, Stoyan D (2008) Statistical Analysis and Modelling of Spatial Point Patterns, Firstth edn. Wiley-Interscience, Chichester, Hoboken

Janik D, Adam D, Hort L, Král K (2014) Tree spatial patterns of Abies alba and Fagus sylvatica in the Western Carpathians over 30 years. Eur J Forest Res 133:1015-1028. doi:10.1007/s10342-014-0819-1

Janzen DH (1970) Herbivores and the number of tree species in tropical forests. The American Naturalist 104:501-528

Johnson DJ, Beaulieu WT, Bever JD, Clay K (2012) Conspecific negative density dependence and forest diversity. Science 336:904-907. doi:10.1126/science. 1220269

Johnson DJ, Bourg NA, Howe R, McShea WJ, Wolf A, Clay K (2014) Conspecific negative density-dependent mortality and the structure of temperate forests. Ecology 95:2493-2503. doi:10.1890/13-2098.1

Kazmierczak M, Backmann P, Fedriani JM, Fischer R, Hartmann AK, Huth A, May F, Müller MS, Taubert F, Grimm V, Groeneveld J (2016) Monodominance in tropical forests: modelling reveals emerging clusters and phase transitions. J The Royal Society Interface 13:20160123. doi:10.1098/rsif.2016.0123

Krueger LM, Peterson CJ, Royo AA, Carson WP (2009) Evaluating relationships among tree growth rate, shade tolerance, and browse tolerance following disturbance in an eastern deciduous forest. Can J Forest Res 39:2460-2469

Larson AJ, Lutz JA, Donato DC, Freund JA, Swanson ME, Hille Ris Lambers J, Sprugel DG, Franklin JF (2015) Spatial aspects of tree mortality strongly differ between young and old-growth forests. Ecology 96:2855-2861. doi:10.1890/ 15-0628.1

Law R, Illian J, Burslem DFRP, Gratzer G, Gunatilleke CVS, Gunatilleke IAUN (2009) Ecological information from spatial patterns of plants: insights from point process theory. J Ecol 97:616-628. doi:10.1111/j.1365-2745.2009.01510.x

Liang SY, Seagle SW (2002) Browsing and microhabitat effects on riparian forest woody seedling demography. Ecology 83:212-227. doi:10.1890/0012-9658(2002) 083[0212:BAMEOR]2.0.CO;2
Long ZT, Pendergast TH IV, Carson WP (2007) The impact of deer on relationships between tree growth and mortality in an old-growth beech-maple forest. Forest Ecol Manage 252:230-238. doi:10.1016/j.foreco.2007.06.034

Messier C, Bellefleur P (1988) Light quantity and quality on the forest floor of pioneer and climax stages in a birch-beech-sugar maple stand. Can J Forest Res 18:615-622. doi:10.1139/x88-090

Murphy SJ, McCarthy BC (2017) Neighborhood interactions and local edaphic gradients have a weak influence on long-term vegetation dynamics in an old-growth forest community. Forest Ecol Manage 389:314-322. doi:10.1016/ j.foreco.2016.12.032

Oliver CD, Larson BC (1996) Forest Stand Dynamics. Wiley, Hoboken

Packer A, Clay K (2000) Soil pathogens and spatial patterns of seedling mortality in a temperate tree. Nature 404:278-281. doi:10.1038/35005072

Packer A, Clay K (2003) Soil pathogens and Prunus serotina seedling and sapling growth near conspecific trees. Ecology 84:108-119. doi:10.1890/00129658(2003)084[0108:SPAPSS]2.0.CO;2

Poulson TL, Platt WJ (1996) Replacement Patterns of Beech and Sugar Maple in Warren Woods, Michigan. Ecology 77:1234-1253. doi:10.2307/2265592

Reinhart KO, Royo AA, Van Der Putten WH, Clay K (2005) Soil feedback and pathogen activity in Prunus serotina throughout its native range. J Ecol 93: 890-898. doi:10.1111/j.1365-2745.2005.01028.x

Reinhart KO, Johnson D, Clay K (2012) Effects of trees on their recruits in the southern Appalachians, USA. Forest Ecology and Management 263:268-274. doi:10.1016/j.foreco.2011.09.038

Rooney TP, Waller DM (2003) Direct and indirect effects of white-tailed deer in forest ecosystems. Forest Ecol Manage 181:165-176. doi:10.1016/S0378$1127(03) 00130-0$

Stutz JC, Frey DR (1980) Altered light levels on growth, fruiting, and leaf characteristics of natural stands of Ilex opaca. HortScience 15:94-96

Takahashi K, Arii K, Lechowicz MJ (2010) Codominance of Acer saccharum and Fagus grandifolia: the role of Fagus root sprouts along a slope gradient in an old-growth forest. J Plant Res 123:665-674. doi:10.1007/s10265-010-0312-y

Terborgh J (2012) Enemies maintain hyperdiverse tropical forests. American Naturalist 179:303-314. doi:10.1086/664183

Tsai Y-HE, Manos PS (2010) Host density drives the postglacial migration of the tree parasite, Epifagus virginiana. Proceedings of the National Academy of Sciences of the United States of America 107:17035-17040

Tubbs CH, Houston DR (1990) Fagus grandifolia Ehrh. American beech. In: Silvics of North America. Department of Agriculture, Forest Service, Washington, D.C, U.S

Virginia Department of Forestry (2014) Beech bark disease in Virginia. Forest Health Review December. p 2-5. http://dof.virginia.gov/infopubs/_fhr/FHR2014-12_pub.pdf

Wagner S, Collet C, Madsen P, Nakashizuka T, Nyland RD, Sagheb-Talebi K (2010) Beech regeneration research: From ecological to silvicultural aspects. Forest Ecol Manage 259:2172-2182. doi:10.1016/j.foreco.2010.02.029

White PS, Jentsch A (2001) The search for generality in studies of disturbance and ecosystem dynamics. Prog Bot 62:399-450

Wiegand T, Gunatilleke S, Gunatilleke N, Okuda T (2007) Analyzing the spatial structure of a Sri Lankan tree species with multiple scales of clustering. Ecology 88:3088-3102. doi:10.1890/06-1350.1

Zhu K, Woodall CW, Monteiro JVD, Clark JS (2015) Prevalence and strength of density-dependent tree recruitment. Ecology 96:2319-2327

\section{Submit your manuscript to a SpringerOpen ${ }^{\circ}$ journal and benefit from:}

- Convenient online submission

- Rigorous peer review

- Open access: articles freely available online

- High visibility within the field

- Retaining the copyright to your article

Submit your next manuscript at $>$ springeropen.com 